\title{
The Impact of Consumer Knowledge/Familiarity with Private Label Brands (PLBs) and Store Image on Perceptions and Preferences toward PLBs and Patronage Intentions: Case of Midscale Department Store PLBs
}

\author{
Yoo-Kyoung Seock ${ }^{\dagger} \cdot$ Jennifer McBride* \\ Dept. of Textiles, Merchandising \& Interiors, The University of Georgia \\ *Belk, Inc. Greenville, SC \\ Received May 3, 2012; Revised June 12, 2012; Accepted June 26, 2012
}

\begin{abstract}
This study examines the impact of consumer knowledge and familiarity with private label brands (PLBs) on perceptions and preferences toward PLBs and patronage intentions; in addition, it examines the incremental effects of a department store image over consumer knowledge and familiarity with perceptions, preferences, and patronage intentions. This study focused on midscale department store PLBs of apparel products and middle age consumers between the ages of 30 and 50 who are the main consumer group of private label brands of apparel products. A structured questionnaire was developed and data were collected from a convenience sample of 257 female consumers between the ages of 35 and 54, living in the Southeastern United States. A factor analysis identified the dimensions of department store image constructs; in addition, a hierarchical regression and multiple regression analyses examined the hypotheses. Consumer knowledge and familiarity with PLBs at department stores is recognized as a major determinant to shape consumer perceptions of and preferences for the PLBs as well as patronage intentions. The present study reveals the significant incremental effect of a store image on consumer preferences, perceptions, and patronage intentions beyond that explained by consumer knowledge and familiarity about PLBs. The study reveals that, among four store image constructs, the store atmosphere and store service factors had significant positive effects on consumer perceptions of PLBs. Store service and atmospheric aspects also affect consumer patronage intentions toward PLBs. The price factor shows a significant and positive influence on the preference consumers have for PLBs, but not on perceptions and patronage intentions. This study has practical implications for department store executives and managers on how to allocate resources in order to increase positive consumer perceptions toward PLBs, preferences over other brands, and patronage intentions of PLBs at a store as well as how to create effective store environments to promote PLBs.
\end{abstract}

Key words: Private label brand, Store image, Knowledge and familiarity, Perception and preference, Patronage

\section{Introduction}

Since private label brands (PLBs) evolved in the United Kingdom, spreading to Canada and the United States, they became of great importance to retailers and consumers over the past decades (Symphony IRI Group, 2006). Until recently, private label brands were

Corresponding author

E-mail: yseock@fcs.uga.edu found primarily in grocery chains, being considered lower priced alternatives to national brand products. However, due to its nature of creating more profit margins for the store with lower priced products, PLBs began rapidly disseminating across other nonfood product categories. With the rising competition in recent retail markets, retailers found that increasing the variety of products with a private label brand (PLB) is one of the ways to satisfy consumers' vari- 
ous needs and wants, and thus, build customer loyalty and create differentiation from the competition. Moreover, as PLBs garnered increased profits for retailers compared to national brands, retailers began stocking their shelves and aisles with exclusive and high quality private labels to satisfy their customers and enlarge their clientele (Stone, 2009). According to the Private Label Manufacturers Association (2009), one in every five products sold in U.S. supermarkets, drug stores, and mass merchandisers in 2008 was from a private label brand. The Private Label Manufacturers Association also states that 60 percent of consumers report buying private label brands on a regular basis, which brought retailers $\$ 80$ billion in 2008, up 22 percent from 2007. In addition, an increasing number of consumers bought private label brands since the economic downturn in 2008 (Lockwood, 2010). Although once private label brands were considered a lower-price, lower-quality substitute for name brands, private label products are now viewed positively by the majority of U.S. consumers. According to a survey by the Nielsen Company, nearly three-quarters (72\%) of American consumers believe that private label products are good alternatives to name brands (Nielsenwire.com, 2008).

Recognizing that branding is crucial in the highly competitive retail market to capture a wider market share and maintain a harmonious relationship with its customers (Dennis et al., 2002), midscale department stores such as Belk, JC Penney and Macy's have placed great emphasis on their private label brands. Beginning with a single PLB, most department stores have launched multiple private label brands (PLBs), varying in style, quality, price, and target market (Symphony IRI Group, 2006), thus affording consumers greater variety in product choices among PLBs offered by the store. As private label brands are considered a differentiator of one store from others, private label brands increasingly cover more sales floor area in midscale department stores, and more energy is devoted to developing and maintaining private label brands. In fact, private-label sales at Macy's and other midscale department stores have been increasing three-times faster than sales of national brands (Eisenberg, 2009). Today private label sales account for up to $50 \%$ of total apparel sales by U.S. department stores, up from $25 \%$ a decade ago (Team, 2010). Moreover, midscale department stores such as Macy's and Kohl's have recently added more private labels. Sales of private label brands at Macy's, for example, represented 19\% of Macy's total sales in 2009 (Macy's, Inc., 2010). Despite increasing trend of private label sales at department stores, these brands often do not have the same name recognition that would come from national or international brands. Besides, with the proliferation of discount retailers such as Wal-Mart and Target, consumers can easily trade down to another store if they are not satisfied with private label merchandise at JC Penney or Macy's. Private label apparel products are not differentiated yet enough to keep fashion-conscious consumers purchasing them in lieu of lower-priced alternatives. If private label products do not excite or interest consumers enough to compel them to spend money, these brands can be a setback to the growth of department stores. Thus, it is imperative that executives of department stores should understand and ensure what consumers expect and want from PLBs in their department stores.

Consumers often gain a great deal of information about PLBs through various channels such as advertising and promotional efforts made by retailers, as well as repeat purchase experiences. The level of knowledge about and familiarity with a brand can be used as a guideline in purchase decisions, influencing preference for purchasing private label brands. Researchers asserted that amount of knowledge about a brand determine overall attitude or perception toward a brand (Keller, 1993; Kim et al., 2008; Romaniuk \& Sharp, 2003). In addition, as brand familiarity reduces uncertainty about a brand, familiarity with a brand could increase the consumer's brand recognition, and influence brand attitude (Collins-Dodd \& Lindley, 2003). Earlier studies also provide evidence that the amount of knowledge and familiarity with a brand affects the patronage of a brand (Flavian et al., 2006; Keller, 1993). As such, much of the existing research literature supports the importance of knowledge and familiarity of a brand on attitude, perception and patronage of the brand; however, questions remain unanswered whether it is applied to private label brands of 
apparel products offered by midscale department stores.

In addition to consumers' knowledge and familiarity about a brand, consumers' attitude toward a brand may be affected by a store's image. Earlier studies suggested the significant impact of retail store image on perceptions and preferences toward a brand (CollinsDodd \& Lindley 2003; Semeijn et al., 2004); store image often serves as leverage for the brand. CollinsDodd and Lindley (2003) further suggested retail store image as a fundamental requirement for a successful differentiation strategy with its PLBs. According to Keller (1993), consumers make assumptions about a brand based on what he or she has already experienced from a particular retailer. Considering its impact on PLB perceptions and preferences, it is vital for retailers to develop a strong, positive store image with various department store environmental cues. Given the growing importance and popularity of PLBs of apparel products at department stores, the present study aims to examine the incremental effect of department store image over consumers' level of knowledge about and familiarity with PLBs on perceptions, preferences toward PLBs and patronage intentions.

While an immense amount of research has been conducted on the benefits and effects of grocery chain PLBs, little research has focused on PLBs of apparel products at department stores. This study focused on midscale department stores' PLBs of apparel products. Midscale department stores are typically anchor stores in shopping malls generally with moderatelypriced merchandise, selling both national brands and their own private labels of apparel products (Vahie \& Paswan 2006). Moreover, approximately half of the midscale department store's floor space consists of private labels of apparel products (Symphony IRI Group, 2006). The present study also focused on middle age consumers aged between 35 and 54, because they are the main consumer group of private label brands for apparel items, according to Coe (1971) and Hoch (1996). More recently, a report by Cotton, Inc. (2010) revealed that mothers of tweens and teens are willing to buy private label brand clothing for their kids at department stores. Today midscale department stores such as JC Penney launched tween brands targeting both tweens and teens and their mothers in order to capture this niche market. Thus, the current study examined consumers who are in between mid-30s and mid-50s. In this study, we excluded those aged over 55 because, according to U.S. Census Bureau, they are considered as being elderly or mature consumers who exhibit different perceptions and behaviours in their shopping activities (Moschis et al., 2003). This study will provide department store executives and managers insight on the perceptions consumers have on the store's private label brands, and grant practical implications regarding how to increase positive PLB perceptions, preferences over other brands, and patronage intentions toward PLBs at a store. The present study may also contribute to department store executives and managers in determining the ultimate components to create effective store environments for promoting PLBs and allocating resources in order to attract consumers to their PLBs. The findings from the study could serve as an important benchmark for PLB marketing strategy.

\section{Literature Review}

\section{PLB Perception}

Perceptions of a brand, or a consumer's attitude toward a brand (Vahie \& Paswan, 2006), are made up of a consumer's emotional perceptions, opinions of quality, and general assessments of a brand (Low \& Lamb, 2000). According to a study conducted by Low and Lamb (2000), when a consumer develops an attitude towards a brand, he or she assesses any functional and symbolic beliefs associated with the brand, as well as the brand's overall advantages, quality, and performance. The combination of these perceptions and one's overall evaluations of a private label brand develop the PLB perceptions. If a consumer's attitude toward a brand is constructive and strong, consumers are more likely to choose that brand and develop patronage towards that brand (Keller, 1993). In 2003, Romaniuk and Sharp found that consumers who have more positive perceptions of brands will have higher patronage to those brands. More recently, Liljander et al. (2009) also found that PLB perceptions determine purchase and repurchase intentions, which in turn leads 
to the actual purchase and repurchase behaviours.

\section{PLB Preference}

PLB preference refers to the tendency of consumers to choose private label brands over national brands in a competing product category (BusinessDictionary. com, 2009). Researchers found that consumers' preferences toward a private label brand over other brands will increase the consumers' inclination to purchase PLBs (Dick et al., 1995). Earlier studies suggested that consumer preference for PLBs stems from multiple antecedents such as consumers' perceptions of store image and the amount of knowledge about and familiarity with PLBs. In 1996, Dick et al. found consumer preference for PLBs is derived from their knowledge and familiarity with private label brands. As consumers become more familiar with PLBs and develop their knowledge structures pertaining to PLBs, they comprehend the brand better and gain knowledge of evaluating and purchasing the brand (Dick et al., 1996). Researchers assert that better brand comprehension escalates confidence in purchasing decisions and increases trust in the brand (Dick et al., 1996; Flavian et al., 2006; Keller, 1993). It is suggested that the increase in brand credibility will then lead to better perceptions of the brand by the consumer (Collins-Dodd \& Lindley, 2003), which will in turn increase the consumer's preference for PLBs (Dick et al., 1996). Familiarity with a brand is believed to moderate alleged risk and quality discrepancies within the brand (Dick et al., 1996). In tests conducted on grocery products, Dick et al. (1996) concluded that this reduction in risk associated with brand familiarity may increase consumer preferences for PLBs.

\section{PLB Patronage Behaviour}

Patronage behaviour, or the repeat purchasing of a brand by consumers (Brink et al., 2006), has been the centre of several previous studies, and is considered by retailers an essential way to achieve success and sustainability of their businesses. Retailers have understood that PLBs are more profitable with higher margins than national brands because of lower produc- tion costs, lower advertising and marketing costs, and the removal of the middle-man. Since PLBs are exclusive at the store and cannot be found in other retail stores, they entice customers with exclusivity and help increase store traffic (Ailawadi et al., 2008). Sudhir and Talukdar (2004) also found that consumers who spend more time in a retail store and purchase more of their PLBs are more likely to make additional purchases at that store. Researchers suggested that PLB patronage provides retailers with negotiating leverage with national brand manufacturers (Ailawadi et al., 2008), higher retail margins on PLBs (Ailawadi et al., 2008; Sudhir \& Talukdar, 2004), higher store loyalty (Ailawadi et al., 2008), less competition from other retailers, and increased advertising and promotional efficiency (Kim et al., 2008). Therefore, it is essential for retailers to understand consumers' PLB patronage intentions and antecedents of their patronage intentions. Earlier studies indicate that PLB patronage behaviour has several antecedents such as store characteristics (store image), PLB perceptions, and PLB cognitive associations, or knowledge of the PLB (Brink et al., 2006). The present study addresses those variables and the relationships between them.

\section{PLB Knowledge and Familiarity}

The Associative Network Theories of Memory (ANT) can be used to explain PLB knowledge and familiarity and their effects on PLB perceptions and PLB patronage behaviour. ANT proposes that "information in memory consists of concepts that are linked together in a network" (Romaniuk \& Sharp, 2003, p. 221). The brand retrieval cues, or the more a consumer knows and associates with a brand, the more his or her brand knowledge acts as a persuader in brand assessment and purchase decisions. PLB knowledge indicates how much a consumer knows about a brand and what associations consumers make with a brand when they think about that brand (Keller, 1993). The quantity, or amount of knowledge, is a determinant of brand attitude or brand perceptions (Keller, 1993; Romaniuk \& Sharp, 2003). The more knowledge a consumer has of a PLB, the better the percep- 
tions of PLBs are formed. Kim et al. (2008) also suggested brand knowledge helps make up brand attitude strength.

PLB familiarity refers to the amount of prior experiences and contact a consumer has had with a brand (Keller, 1993). More familiarity with a PLB should increase the consumer's brand recognition, and influence brand attitude (Collins-Dodd \& Lindley, 2003) because brand familiarity reduces uncertainty about a brand, adds trust toward the brand, and aids in the development of knowledge structures associated with a brand (Flavian et al., 2006). In addition, familiarity increases self-confidence in purchasing decisions, increasing the occurrence of making that decision. As the occurrence of making the decision to purchase a PLB increases, PLB patronage increases. According to Baltas (1997), PLB familiarity reduces the risky association with purchasing PLBs as well. PLB repurchasing behaviour then increases due to the decreased risks and increased confidence in receiving pleasing product performance. Hence, familiarity with a brand can affect consumer decision-making processes, such as developing perceptions and making purchase decisions.

Prior research provides evidence that the amount of PLB knowledge and familiarity affects the patronage of PLBs. Keller (1993) suggests that the shortterm effects of advertising and promotional efforts by a retailer develop knowledge about a brand and affect sales of the brand. As brand knowledge increases, the likelihood of the brand being chosen by the consumer for purchase increases. Consumers tend to confine their choices to brands of greater familiarity. When consumers do so, the brand's likelihood of purchase is increased and patronage behaviours towards the brand are developed (Flavian et al., 2006). Also, with higher brand knowledge and a more positive perception of the brand, brand loyalty and repurchase behaviour increases.

\section{Store Image}

Store image (SI) refers to the overall perceptions consumers hold about a store, including the physical (layout, convenience, selection) and psychological or social (quality, atmosphere, experiential feelings and emotions) aspects of the store. A consumer uses signals from the perceived physical, service, quality, and other experiential factors of a store to form attitudes toward the store (Burt \& Mavrommatis, 2006). SI is considered a valuable asset for many retailers, providing added value and credibility to the stores and brands (Martenson, 2007). Previous research has established that a positive SI is linked to increased store success and store loyalty. A great number of past studies have emphasized the relationship between store image and store patronage. However, little work has been done to determine the relationship between store image and brand patronage, and even less has focused on its relationship with PLB patronage.

The attribution theory explains how consumers make subjective assumptions about a product from limited information or data (Vahie \& Paswan, 2006). This data can include experience or other factors, such as the retail store image. When consumers do not have much experience with a brand and lack a brand schema, or cognitive structure, for a PLB, consumers tend to look for other cues to aid in creating perceptions toward that PLB (Akhter et al., 1994). In this case, the store image can serve as leverage for the brand, where the consumer makes assumptions about a PLB based on what he or she already knows about a particular retailer (Keller, 1993). Therefore, according to the attribution theory, it is likely that store image will significantly affect the consumers' PLB perceptions, preferences toward PLBs, and patronage intentions since PLBs are store exclusive (Vahie \& Paswan, 2006). The cue utilization theory also proposes that SI can influence the perceptions of PLBs, since store associations can be used to develop perceptions about PLBs (Collins-Dodd \& Lindley, 2003). For example, if a consumer believes a department store to be fashionable, he or she will likely believe the department store's PLBs to be fashionable. Also, if a consumer believes a department store to be of poorer scale, he or she will likely believe the department store's PLBs to be dated or of lower quality. Morganosky (1990) studied the effects of store image on brand quality perceptions by comparing consumer perceptions of brands from department stores, 
discount stores, chain stores, and off-price stores. The study indicated that consumers perceived the brands from department stores to be significantly higher in quality than brands from any of the other retail types (Liljander et al., 2009). According to Visser et al. (2006), developing a strong, positive SI is crucial for retailers due to its influence on PLB perceptions and its aiding in store differentiation.

Previous studies suggest purchase decisions, such as patronage behaviour, are influenced by a store's image (Akhter et al., 1994; Semeijn et al., 2004). According to Martenson (2007), retail store images have a positive relationship with brand patronage, and many retailers use their store image as a means of promoting their PLBs. Store image provides the customer with an added value to the product as well as familiarity, credibility, and confidence in the store's ability to produce products. Associations with store image may make it easier for consumers to try PLBs, which are commonly less well known. Retailers can then increase loyalty towards their PLBs by developing PLBs that are consistent with a store's SI.

\section{Research Hypotheses}

The Associative Network Theories of Memory (ANT) elucidates PLB knowledge and familiarity and their effects on PLB perceptions and PLB patronage behaviour. Existing evidence from the research supported the impact of knowledge and familiarity of a brand on attitude, perception and patronage of the brand (Collins-Dodd \& Lindley, 2003; Flavian et al., 2006; Keller, 1993; Kim et al., 2008; Romaniuk \& Sharp, 2003). In this vein, the present study, first of all, endeavored to examine whether this notion applies to private label apparel products offered by department stores. This study, further, examined the incremental effect of department store image over consumer knowledge and familiarity of PLBs on perceptions, preferences and patronage behaviors. Earlier researchers pointed out the importance of retail store image on perceptions and preferences toward a brand (Collins-Dodd \& Lindley, 2003; Semeijn et al., 2004) and patronage behaviour (Akhter et al., 1994; Semeijn et al., 2004). Furthermore, Collins-Dodd and Lind- ley (2003) and Martenson (2007) suggested that retail store image serves as leverage for a brand and can be used as a means of promoting the store's PLBs, in addition to other branding strategies. Thus, the current study attempted to discover whether retail store image can account for a significant increment in determining the effect on preferences, perceptions and patronage intentions above and beyond that being explained by consumer knowledge and familiarity. Besides, researchers found that positive perceptions of brands lead to higher patronage behaviour to those brands and repurchase intention (Liljander et al., 2009; Romaniuk \& Sharp, 2003). Dick et al. (1995) asserted that consumers' preferences toward a private label brand over other brands will increase the consumers' inclination to purchase PLBs. Derived from the Associative Network Theories of Memory and the previous literature on knowledge and familiarity of PLBs, store image, perceptions and preferences toward PLBs and patronage intentions, the following research hypotheses were formulated for the study (Fig. 1).

H1-1. Consumer knowledge and familiarity of PLBs will have a significant influence on PLB perceptions.

H1-2. There will be an incremental effect of store image over consumer knowledge and familiarity of PLBs in determining the effect on PLB perceptions.

H2-1. Consumer knowledge and familiarity of PLBs will have a significant influence on preferences toward PLBs.

$\mathrm{H} 2-2$. There will be an incremental effect of store image over consumer knowledge and familiarity of PLBs in determining the effect on preferences toward PLBs.

H3-1. Consumer knowledge and familiarity of PLBs will have a significant influence on PLB patronage intentions.

H3-2. There will be an incremental effect of store image over consumer knowledge and familiarity of PLBs in determining the effect on PLB patronage intentions.

H4. PLB perceptions and preferences toward PLBs will have significant influences on PLB patronage intentions. 


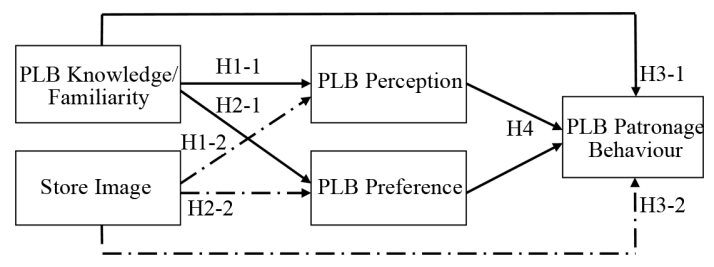

Dotted lines indicate incremental effect of a store image over consumer knowledge and familiarity of PLBs on each dependent variable.

Fig. 1. Proposed research model.

\section{Research Methods}

\section{Sample and Data Collection}

The population for the current study comprises female consumers whose ages range between 35 and 54. A structured questionnaire was distributed to a convenience sample of 300 female consumers aged between 30 and 50s, living in a South-eastern state of the United States. In order to collect data, the researcher contacted local department store managers to get permission to conduct the survey at their stores. The midscale department stores included in this study were Belk, JC Penney and Macy's, which rely heavily on private label brands in addition to selling products from other companies. Belk offers exclusive private label brands, such as Madison, Red Camel, Kim Rogers and Biltmore. JC Penney has a number of private label brands including Arizona Jeans Co., Stafford, St. John's Bay and Towncraft. Macy's also carries various private label brands, such as Alfani, American Rag, Charter Club, Hotel Collection, I.N.C. and Style \& Co. Times were arranged to visit the department stores for the purpose of administering the surveys, and the researcher stood by several entrances of three major midscale department stores (Belk, JC Penney, and Macy's) in two south-eastern cities, distributing the surveys to any customers who appeared to possibly meet the profile. Participation was voluntary, and no incentives were offered for participation. The stores were visited during various days and time ranges, including weekdays and weekends during morning, mid-day, and evening hours.
Of the 300 surveys distributed and returned, 257 responses were used for data analysis after eliminating those completed incorrectly or missed too many questions and by the respondent who did not meet the sample criteria.

\section{Instrument Development}

A structured questionnaire was developed to collect data. The questionnaire began by asking the participants demographic questions, such as age, gender, income, and education level. The questionnaire then asked participants a series of questions with regard to their experience and opinions of their favourite department store in order to validate that the participants were frequent department store shoppers and that their opinions about department store image and private label brands were significant. The remainder of the questionnaire provided participants with a statement, and asked them to rank the statement on a five point Likert scale ( 1 = Strongly Disagree; 5 = Strongly Agree).

In order to measure store image with various retail store environmental cues, sixteen items were adapted from Vahie and Paswan (2006). Participants were asked to rank how they agree or disagree with statements such as "The employees are very friendly," "The store is easy to shop in," "The prices at the store are fair," and "The appearance of the store is appealing." Adapted from the study of Flavian et al. (2006), consumer knowledge and familiarity of private label brands in department stores was measured by asking questions about the consumers' amount of perceived knowledge and familiarity with the PLBs of their favourite department store. Five statements were used to measure this variable. Statements, including "I know a lot about the private label brands of my favourite department store" and "I can tell a difference between private label brands and national brands offered by my favourite department store," measured the knowledge the consumer believes himself or herself to have of the department store's private label brands. Other statements, including "In comparison with the typical purchaser, I believe I am quite familiar with the private label brands offered by the store," mea- 
sured the perceived familiarity of the consumer with the department store's private label brands.

To measure consumer preferences for private label brands, participants were given three statements created by the researcher, such as "I shop at my favourite department store because I like the private label brands it carries" and "I prefer to purchase private label brands of my favourite department store rather than national brands." Perceptions consumers have of private label brands were measured in the questionnaire using four items adapted from Liljander et al. (2009). The questionnaire contained statements such as "I consider the private label brands to be a good choice" and "I believe that private label brand items will be of high quality." Finally, the questionnaire adapted five items from various studies by Liljander et al. (2009), Kim et al. (2007), and Matzler et al. (2008) in order to measure consumers' patronage intentions toward private label brands in department stores. This section of the questionnaire sought to determine the likelihood that the consumer will make future purchases of department store PLBs. Participants were asked to rate how much they agree or disagree with a proposed statement, such as "I will definitely consider buying a private label brand," "I will buy private label brands the next time I shop at my favourite department store," and "I would be willing to pay a higher price for the private label brands of the department store over other brands." The content validity of the questionnaire was assessed through examination by a panel of three experts in the area. Initial changes were made to clarify or delete some statements according to recommendations or comments of the experts. Based on the feedback collected from the pilot test, the instrument was revised to improve the clarity of the questions and to increase the content validity of the measurement instrument.

\section{Data Analysis and Results}

Data gathered from the survey was analyzed using the Statistical Package for Social Science (SPSS) program. The data analysis consisted of descriptive statistics, exploratory factor analysis and multiple regression analysis. Cronbach's alpha values were com- puted to assess the internal consistency aspect of reliability of the multi-item scales measuring store image (0.72), knowledge and familiarity of PLBs (0.91), preference for PLBs (0.96), perceptions of PLBs (0.90), and consumers' patronage intentions toward PLBs (0.87). In preparation for testing Hypotheses, scores for PLB perceptions, preferences toward PLBs, and patronage intentions were computed by summating the items in each scale.

\section{Demographic Profile of the Sample}

When asking frequency of purchasing clothing items at department stores, approximately $40 \%$ of respondents reported that they occasionally purchased clothing items at department stores. More than half of the respondents (55\%) answered that they often purchased clothing items at department stores. All respondents reported they have a favourite department store. Based on the demographic information provided by the respondents, slightly over half of respondents $(52 \%)$ had four-year college degree (B.A./ B.S.) and $22 \%$ of them held graduate degree (M.S./ M.A./MBA/Ph. D.) or professional degree. The income frequency revealed that $9 \%$ of the respondents reported annual household incomes of less than $\$ 20,000$ before tax, while $11 \%$ reported household incomes over $\$ 70,000$ per year. Around 38 percent of them had a total of annual household incomes between $\$ 25,000$ and under $\$ 40,000$ per year, $31 \%$ between $\$ 40,000$ and under $\$ 55,000$, and $11 \%$ between $\$ 55,000$ and less than $\$ 70,000$.

\section{Preliminary Analysis}

A principle component of factor analysis with varimax rotation was conducted to identify the constructs of department store image. To set the criteria for the factor analysis, factors with eigenvalues greater than 1.0 and items with rotated factor loadings of 0.50 or greater were retained because factor loadings of 0.50 or greater are considered statistically and practically significant (Hair et al., 1998). To ensure that each factor would have only one dimension, any items loading on more than one factor with a loading score 
equal to or greater than 0.40 on each factor were eliminated from the analysis. In addition, because communality of a variable represents the amount of variance in the factor solution explained by that variable (Hair et al., 1998), variables with communalities less than 0.40 were deleted for reasons of insufficient contribution to explaining the variance. Variables that did not meet the above criteria were excluded from the analysis. Of the total 16 items, 12 items of department store image cues were retained for the factor analysis, and four constructs were identified: Store Atmosphere, Service, Price, and Convenience (Table 1). A total of $76.21 \%$ variance was explained by these four store image factors in the study.

\section{Hypotheses Testing}

In order to assess the impacts of consumer knowledge and familiarity of PLBs and department store image on consumers' perceptions of PLBs (H1), preferences of PLBs (H2) and patronage intentions (H3), three separate hierarchical multiple regression analyses using enter method were conducted. Derived from the Associative Network Theories of Memory and the previous literature on brand, knowledge and familiarity of PLBs was first entered into the regression equation in each hierarchical regression analysis, and then four store image constructs were entered into the equation. In this way, the correlations between knowledge and familiarity of PLBs and four store image constructs were partialled out of the regression analyses, allowing the researcher to examine a significant incremental increase in $\mathrm{R}^{2}$ after controlling the effect of knowledge and familiarity of PLBs on each dependent variable. Thus, we can understand how much additional variance in preferences, perceptions and patronage intentions can be explained by store image. In these analyses, knowledge/familiarity with PLBs and four department store image constructs were independent variables, and each of the perception of PLBs (H1), preferences of PLBs (H2) and patronage intentions (H3) was dependent variable. The hierarchical regression analyses results for the hypothesis 1,2 , and 3 are reported in $<$ Table $2>$. Multiple regression analysis result for the hypothesis 4 is reported in $<$ Table $3>$.

\section{1) Hypothesis 1}

First of all, consumer knowledge and familiarity of PLBs was first entered into the regression equation in order to examine the influence of knowledge and familiarity with PLBs on the perceptions of PLBS (H1-1). The regression model (model 1 for H1-1) was significant, with $F(1,256)=121.06$ and $p<.001$, indicating that $32.2 \%$ of the variance in the perceptions of PLBs at department stores was explained only by knowledge and familiarity with PLBs. H1-1

Table 1. Factor analysis of store image

\begin{tabular}{|c|c|c|c|c|c|}
\hline Factors & Items & $\begin{array}{l}\text { Factor } \\
\text { loading }\end{array}$ & $\begin{array}{l}\text { Eigen } \\
\text { value }\end{array}$ & $\begin{array}{c}\text { Variance } \\
\text { explained }\end{array}$ & $\begin{array}{l}\text { Cronbach's } \\
\text { alpha }\end{array}$ \\
\hline \multirow{4}{*}{$\begin{array}{c}\text { Factor 1: } \\
\text { Store } \\
\text { Atmosphere }\end{array}$} & The store is old-fashioned. (R) & 0.85 & \multirow{4}{*}{2.74} & \multirow{4}{*}{$22.81 \%$} & \multirow{4}{*}{0.82} \\
\hline & The store is dirty. (R) & 0.84 & & & \\
\hline & The appearance of the store is appealing. & 0.83 & & & \\
\hline & The employees are dressed appropriately and neat. & 0.65 & & & \\
\hline \multirow{3}{*}{$\begin{array}{l}\text { Factor 2: } \\
\text { Service }\end{array}$} & The service is excellent. & 0.94 & \multirow{3}{*}{2.74} & \multirow{3}{*}{$22.81 \%$} & \multirow{3}{*}{0.93} \\
\hline & I am pleased with the service I receive. & 0.90 & & & \\
\hline & The employees are very friendly. & 0.89 & & & \\
\hline \multirow{3}{*}{$\begin{array}{c}\text { Factor 3: } \\
\text { Price }\end{array}$} & The prices at the store are fair. & 0.91 & \multirow{3}{*}{2.12} & \multirow{3}{*}{$17.62 \%$} & \multirow{3}{*}{0.68} \\
\hline & I obtain value for my money at the store. & 0.84 & & & \\
\hline & I can purchase clothes for less at the store. & 0.73 & & & \\
\hline \multirow{2}{*}{$\begin{array}{c}\text { Factor 4: } \\
\text { Convenience }\end{array}$} & The store is easily accessible from the parking lot. & 0.85 & \multirow{2}{*}{1.56} & \multirow{2}{*}{$12.97 \%$} & \multirow{2}{*}{0.70} \\
\hline & The store is easy to shop in. & 0.84 & & & \\
\hline
\end{tabular}

(R) means reverse coded. 
Table 2. Hierarchical regression analyses results

\begin{tabular}{c|c|c|c|c|c|c}
\hline \hline \multirow{2}{*}{ Variables } & \multicolumn{2}{|c|}{ PLB Perception $(\mathrm{H} 1)$} & \multicolumn{2}{c|}{ PLB Preference $(\mathrm{H} 2)$} & \multicolumn{2}{c}{ PLB Patronage Intention (H3) } \\
\cline { 2 - 7 } & Model 1 $(\beta)$ & Model 2 $(\beta)$ & Model 1 $(\beta)$ & Model 2 $(\beta)$ & Model 1 $(\beta)$ & Model 2 $(\beta)$ \\
\hline PLB Knowledge/Familiarity & $.587^{* * *}$ & $.586^{* * *}$ & $.551^{* * *}$ & $.530^{* * *}$ & $.597^{* * *}$ & $.596^{* * *}$ \\
\hline Store Atmosphere & & $.234^{* * *}$ & & $.127^{*}$ & & $.184^{* * *}$ \\
\hline Service & & $.168^{* *}$ & & .102 & & $.194^{* * *}$ \\
\hline Price & & -.021 & & $.127^{*}$ & & .075 \\
\hline Convenience & & -.081 & & -.090 & & -.105 \\
\hline $\mathrm{R}^{2}$ & .322 & .414 & .303 & .345 & .356 & .437 \\
\hline $\mathrm{F}$ & $121.06^{* * *}$ & $35.49^{* * *}$ & $110.95^{* * *}$ & $26.46^{* * *}$ & $140.92^{* * *}$ & $38.89^{* * *}$ \\
\hline
\end{tabular}

$* p<.05, * * p<.01, * * * p<.001$

Independent variables: PLB knowledge/familiarity, store atmosphere, service, price, and convenience

Dependent variables: PLB perception (H1), PLB preference (H2), and PLB patronage intention (H3)

Table 3. Multiple regression analysis result for Hypothesis 4

\begin{tabular}{l|c|c|c}
\hline \hline $\begin{array}{c}\text { Independent } \\
\text { Variables }\end{array}$ & DF & $\begin{array}{c}\text { Standardized } \\
\text { Coefficient }(\beta)\end{array}$ & t-value \\
\hline PLB Perception & 2 & .69 & $15.85^{* * *}$ \\
\hline PLB Preference & 2 & .22 & $5.10^{* * *}$ \\
\hline $\mathrm{R}^{2}$ & 0.744 \\
\hline$F(2,256)$ & 369.72 \\
$\begin{array}{l}* * * p<.001 \\
\text { Dependent variable: PLB patronage intention }\end{array}$
\end{tabular}

was supported. Then four store image constructs were entered into the regression equation in order to determine the incremental effect of store image factors over consumer knowledge and familiarity of PLBs on perceptions (H1-2). The overall regression model (model 2 for H1-2) was significant, with $F$ (5, $256)=39.49$ and $p<.001$, indicating that $41.4 \%$ of the variance in the perceptions of PLBs at department stores was explained by both knowledge/familiarity of PLBs and department store image. In this hierarchical regression model, significant $\mathrm{F}$ change was $p=.000$, suggesting significant incremental effects of store image constructs over consumer knowledge and familiarity of PLBs in determining the effect on perceptions of PLBs. Thus, Hypothesis 1-2 was supported. When testing the relative contributions of independent variables to explain consumers' perceptions of PLBs at department stores, consumer knowledge and familiarity of PLBs $(\beta=.59, p<.001)$ was the strongest and significant indicator of the percep- tions of PLBs. Among four department store image constructs, store atmosphere factor $(\beta=.23, p<.001)$ and service factor $(\beta=.17, p<.01)$ were the significant determinants of the perceptions of PLBs.

\section{2) Hypothesis 2}

In order to assess the influence of consumer knowledge and familiarity of PLBs on consumers' preferences of PLBs (H2-1), knowledge and familiarity of PLBs was first entered into the regression equation. The regression model (model 1 for H2-1) was significant, with $F(1,256)=110.95$ and $p<.001$, indicating that $30.3 \%$ of the variance in the preferences of PLBs at department stores was explained only by knowledge and familiarity with PLBs. H2-1 was supported. When four store image constructs were entered into the regression equation in order to determine the incremental effect of store image factors over consumer knowledge and familiarity of PLBs on preferences of PLBs (H2-2), the overall regression model (model 2 for $\mathrm{H} 2-2)$ was significant, with $F$ (5, $256)=26.46$ and $p<.001$, indicating that $34.5 \%$ of the variance in the preferences of PLBs at department stores was explained by both knowledge/familiarity of PLBs and department store image. In this hierarchical regression model, significant $\mathrm{F}$ change was $p=.004$, suggesting significant incremental effects of store image constructs over consumer knowledge and familiarity of PLBs in determining the effect on preferences toward PLBs. Thus, Hypothesis 2-2 was supported. The test of the relative contributions of in- 
dependent variables to explain consumers' preferences of PLBs at department stores showed that knowledge and familiarity of PLBs $(\beta=.53, p<.001)$ was the strongest and significant indicator of the perceptions of PLBs. Among four department store image constructs, store atmosphere factor $(\beta=.13, p<.05)$ and price factor $(\beta=.13, p<.05)$ were the significant determinants of the preferences of PLBs.

\section{3) Hypothesis 3}

In predicting the influence of knowledge and familiarity of PLBs on patronage intentions (H3-1), the regression model (model 1 for $\mathrm{H} 3-1$ ) was significant, with $F(1,256)=140.92$ and $p<.001$, indicating that $35.6 \%$ of the variance in patronage intentions of PLBs at department stores was explained only by consumer knowledge and familiarity of PLBs. H3-1 was supported. When four store image constructs were entered into the regression equation in order to examine the incremental effect of store image factors over consumer knowledge and familiarity of PLBs on patronage intention, the overall regression model (model 2 for H3-2) was significant, with $F(5,256)=38.89$ and $p<.001$, indicating that $43.7 \%$ of the variance in the patronage intentions of PLBs at department stores was explained by both knowledge/familiarity of PLBs and department store image. In the hierarchical regression model, significant $\mathrm{F}$ change was $p=.000$, suggesting the incremental effects of store image constructs over knowledge and familiarity of PLBs in determining the effect on patronage intentions of PLBs. Thus, Hypothesis 3-2 was supported. The test of the relative contributions of independent variables to explain consumers' preferences on PLBs of department stores showed that consumer knowledge and familiarity of PLBs $(\beta=.60, p<.001)$ was the strongest and the most significant indicator of PLB patronage intentions. Store atmosphere $(\beta=.18, p<.001)$ and service factor $(\beta=.19, p<.001)$ were the significant determinants of the patronage intentions of PLBs.

\section{4) Hypothesis 4}

Multiple regression analysis was conducted to examine the influence of PLB perceptions and preferences toward PLBs on PLB patronage intentions. In this analysis independent variables were PLB perceptions and preferences toward PLBs and the dependent variable was patronage intentions. The regression analysis results for the relationship between PLB perceptions and preferences toward PLBs and patronage intentions are reported in $<$ Table $3>$. The regression model was significant, with $F(2,256)=$ 369.72 and $p<.001$, indicating that $74.4 \%$ of the variance in the PLB patronage intentions at department stores was explained by both PLB perceptions and preferences toward PLBs. Thus, Hypothesis 4 was supported. The test of the relative contributions of independent variables to explain PLB patronage intentions showed that both PLB perceptions $(\beta=.69$, $p<.001)$ and preferences toward PLBs $(\beta=.23, p<$ $.001)$ were significant indicators of PLB patronage intentions. However, PLB perception was a stronger indicator of patronage intention than preference toward PLBs.

\section{Discussion and Implications}

Whereas a significant amount of attention has been directed toward private label brands (PLBs), there has been very limited academic research to date that has shed light on private label blends of apparel products at department stores. The current study was designed as an exploratory study to gain insight into middle aged female consumers' perceptions, preferences and patronage intentions of private label brand of apparel at the department store with a focus on the impact of knowledge/familiarity with PLBs and department store image on consumers' perceptions, preferences and patronage intentions of PLBs. The present study, in particular, examined the incremental effect of department store image over consumer knowledge and familiarity of PLBs in determining the effect on PLBs perceptions, preferences, and patronage intentions toward PLBs in department stores. In addition, the present study also determined the influence of private label brand perceptions and preferences on patronage intentions.

The results of the present study demonstrate that consumers' knowledge and familiarity with PLBs at department stores is a major determinant in shaping 
their perceptions of and preferences for the PLBs and, thus, their patronage intentions. This finding aligns with a study by Romaniuk and Sharp (2003) that suggested knowledge about a brand serves as a determinant of the attitude toward a brand. That is, the more consumers know about PLBs and the more familiar they are with PLBs, the more positively consumers view them. As knowledge structures are built in the consumer's mind, positive perceptions and preferences toward PLBs also grow, which lead to their patronage behaviour with PLBs. According to Keller (1993), advertising and promotional efforts by a retailer create knowledge about a brand in the consumers' minds and strengthen consumers' attitudes toward the brand, which determines the brand's level of success. The results of the current study further confirm Keller's (1993) proposition and suggest that when consumers are more exposed to a store's PLBs, whether through actual usage, advertising, or promotional efforts, they may view PLBs to be as good as national brands or better and develop preferences for PLBs over other brands. When consumers have more knowledge about and experience with PLBs, they may demonstrate higher credibility over other national brands, resulting in greater preference for the PLB (Dick et al., 1996). Such preference could inspire greater loyalty to the store, since PLBs are store exclusive. Since greater knowledge and familiarity increase the favourability toward PLBs, department store retailers should make extra efforts to create awareness and build consumer knowledge and familiarity with PLBs. Advertising through various media and in-store promotions are means by which consumers can be exposed to the PLBs as well as learn more about the brand. The results also show that knowledge and familiarity of PLBs is found to directly influence whether consumers purchase PLBs, while also indirectly influencing perceptions and preferences. That is, the more consumers know about PLBs and the more familiar consumers become with them, the more likely they are to repeat purchase PLBs at department stores. The results support the Associated Network Theories of Memory, which state that information in one's memory is made up of concepts linked together in a network, and, therefore, what one knows about a brand persuades one's purchase intentions (Romaniuk \& Sharp, 2003). Based on this study, it can be concluded that the more exposure consumers have to a PLB, the more likely they are to purchase the PLB.

Hierarchical regression analyses results reveal significant $\mathrm{F}$ changes when four store image constructs were entered into the regression equations, suggesting significant incremental effect of store image over consumer knowledge and familiarity of PLBs in determining the effect on perceptions, preferences and patronage intentions toward PLBs. This finding supports the notion from Collins-Dodd and Lindley (2003) and Martenson (2007) that retail store image may serve as leverage for a brand and can be used as a means of promoting the store's PLBs. The present study, in particular, reveals that the store atmosphere and in-store service factors have significant positive effects on consumers' perceptions of PLBs. Consumers' patronage intentions toward PLBs are also affected by store service and atmospheric aspects. The more impressed the customer is with the service and store atmosphere, the more likely it is that he or she perceives PLBs positively and favourably. The results of the study suggest that customer service and store atmosphere are the key environmental cues for obtaining consumers' positive perceptions toward PLBs and also for influencing repeat purchase intentions of PLBs at the department store. The findings imply that sales personnel's appearance, attitude, and manner toward their customers, in addition to favourable store services and policies are crucial for the success of PLBs. The findings of the study also suggest that creating a visually appealing store design with up-todate product displays and well-organized store layout might be essential in order to increase consumers' positive perceptions and repeat visit to the store and repurchase PLBs of the store. These findings could provide fundamental guidelines for department store executives and managers who attempt to resurrect or improve their retail store's environment and attract consumers to their PLBs. The results of the study suggest that department store executives and managers should make extra efforts on the services and overall environment at the store and set specific stan- 
dards for it. The store managers should encourage their sales associates to practice services according to the standards and proper procedures, and ensure that those standards are being met. For example, sales associates may be expected to approach customers after they enter the department store, check in on customers in the dressing room, offer to assist customers with their needs, keep an upbeat and helpful attitude through the customer's entire shopping experience, and so on. In addition, department store retailers need to offer flexible store return and exchange policies. The more that customers feel the service level is satisfactory, the more likely they are to purchase the store's PLBs, because they see the store and its brands in a more favourable manner. Stores may be able to monitor the service the associates give through customer surveys to ensure the service is as high as possible in the effort to increase sales of private label brands. The department store executives and managers also should put an emphasis on creating appealing store environment and keeping it up-to-date and clean. By doing so, department store retailers may be able to give their retail stores a unique and positive image and, thus, strongly market their PLBs to customers who visit the store. Consumers are often involved in multiple activities when shopping and may make their store selections accordingly. Thus, the proximity to other shopping facilities might be one of the advantages of department stores in terms of consumer store choices. Consumers may use department stores more frequently than other types of retail formats partly because department stores carry a wide variety of product categories beyond apparel items and are convenient to shop in, so consumers can accomplish multiple purposes of their shopping trip by visiting one place. Therefore, PLBs supported by excellent services and appealing store environment at the department stores may have a great chance to attract consumers to the store and win sales of PLBs.

In this study, the price factor shows a significant and positive influence on the preference consumers have for PLBs. If consumers felt that they were receiving a lower price with better value for their money with specific PLBs, they would prefer these PLBs over other brands and are likely to repeat pur- chase PLBs. This result suggests that the department store executives should pay close attention to the price factor of their PLBs and keep in mind that when consumers feel that they are able to get the best deals from PLBs, they prefer PLBs over other brands. Moreover, offering a wide range of price points based on the quality of PLB products is a way to diversify their brands and products, granting their customers options from which to choose. However, it is interesting to find that the price did not directly influence consumers' patronage intentions at the department store. Moreover, although the price factor was not a significant determinant of perceptions toward PLBs, it was negatively related to the perception of PLBs. When examining the influence of perceptions and preferences of PLBs on patronage intentions, both are significant indicator of patronage intentions of PLBs. However, perception of PLBs was a better indicator of patronage intentions than preferences of PLBs. Overall, department store atmosphere and in-store service aspects are keys to shape a positively perceptions of PLBs and patronage intentions accordingly.

The results of the present study offer insight for private label brand retailers of apparel products. The success of private label brands may depend on offering superior store environment, along with effective advertising and promotional efforts. Placing emphasis on enriching the presentation of private label brands with efficient signage in a pleasant store environment may be an approach to provide differentiated features in the store, and impress the consumers who visit the store. Once consumers are exposed to the PLBs and attain positive information about the brands, they are more likely to perceive PLBs positively and also repeat purchase PLBs, regardless of price. This study has practical implications for department store executives and managers regarding how to increase sales of PLBs and loyalty to the store. However, like many other empirical studies, this study has some limitations that should be considered when interpreting its results. As the sample was limited to the individuals in one South-eastern state in the United States with a sample size of 257 , the findings from the study cannot be generalized to all populations. Future study need to expand with a larger sample that includes other 
geographical areas of the United States. This study included only female consumers, excluding male consumers. Future research needs to include male consumers and explore the differences between female and male in the variables in the current study. In addition, future study also needs to include other variables that might shed greater insights into consumers' shopping behaviours with private label brand. For example, it would be interesting to incorporate other variables such as advertisement and promotional efforts made by private label retailers and aesthetic aspects of store environment (i.e., music, lighting, window displays), and examine the effects of those variables on PLBs shopping behaviour.

\section{References}

Ailawadi, K. L., Pauwels, K., \& Steenkamp, J. E. M. (2008). Private label use and store loyalty. Journal of Marketing, 72(6), 19-30.

Akhter, S. H., Andrews, J. C., \& Durvasula, S. (1994). The influence of retail store environment on brand-related judgments. Journal of Retailing and Consumer Services, 1(2), 67-76.

Baltas, G. (1997). Determinants of store brand choice: A behavioural analysis. Journal of Product and Brand Management, 6(5), 315-324.

BusinessDictionary.com. (2009). Brand Preference. BusinessDictionary.com. Retrieved March 21, 2010, from http:// www.businessdictionary.com/definition/brand-preference.html

Brink, D., Odekerken-Schroder, G., \& Pauwels, P. (2006). The effect of strategic and tactical cause-related marketing on consumers' brand loyalty. Journal of Consumer Marketing, 23(1), 15-25.

Burt, S., \& Mavrommatis, A. (2006). The international transfer of store brand image. The International Review of Retail, Distribution, and Consumer Research, 16(4), 395-413.

Coe, B. D. (1971). Private versus national preference among lower- and middle-income Consumers. Journal of Retailing, 47(3), 61-72.

Collins-Dodd, C., \& Lindley, T. (2003). Store brands and retail differentiation: The influence of store image and store brand attitude on store own brand perceptions. Journal of Retailing and Consumer Services, 10(6), 345-352.

Cotton, Inc. (2010). Young, impressionable and on mom's budget. Life Style Monitor. Retrieved June 5, 2012, from
http://lifestylemonitor.cottoninc.com/LSM-Issue-Summer-2010/Tweens-Buying-Influence

Dennis, C., Murphy, J., Marsland, D., Cockett, T., \& Patel, T. (2002). Measuring image: Shopping centre case studies. The International Review of Retail, Distribution, and Consumer Research, 12(4), 355-373.

Dick, A., Jain, A., \& Richardson, P. (1995). Correlates of store brand proneness: Some empirical Observations. Journal of Product and Brand Management, 4(4), 1522.

Dick, A., Jain, A., \& Richardson, P. (1996). Household store brand proneness: A framework. Journal of Retailing, 72(2), 159-185.

Eisenberg, L. (2009). Shoptimism: Why the American consumer will keep on buying no matter what. Shoptimism. Retrieved June 1, 2012, from http://www.shoptimismbook.com/excerpts/from-the-prologue-the-world-stuffedinto-a-little-black-dress/

Flavian, C., Guinaliu, M., \& Gurrea, R. (2006). The influence of familiarity and usability on loyalty to online journalistic services: The role of user experience. Journal of Retailing and Consumer Services, 13(5), 363375.

Hair, J. F., Anderson, R. E., Tatham, R. L., \& Black, W. C. (1998). Multivariate data analysis (5th ed.). Upper Saddle River, NJ: Prentice Hall.

Hoch, S. J. (1996). How should national brands think about private labels. Sloan Management Review, 37(2), 89102.

Keller, K. L. (1993). Conceptualizing, measuring, and managing customer-based brand equity. Journal of Marketing, 57(1), 1-22.

Kim, J., Fiore, A. M., \& Lee, H. H. (2007). Influences of online store perception, shopping enjoyment, and shopping involvement on consumer patronage behaviour towards an online retailer. Journal of Retailing and Consumer Services, 14(2), 95-107.

Kim, J., Morris, J. D., \& Swait, J. (2008). Antecedents of true brand loyalty. Journal of Advertising, 37(2), 99-117.

Liljander, V., Polsa, P., \& Riel, A. (2009). Modelling consumer responses to an apparel store brand: Store image as a risk reducer. Journal of Retailing and Consumer Services, 16(4), 281-290.

Lockwood, L. (2010, August 12). Celebrity, proprietary brands squeeze independent labels. WWD. Retrieved June 5, 2012, from http://www.retailgeeks.com/wp-content/uploads/2010/08/2010_0812_CelebrityBrandsSqueezeIndependentLabels.pdf

Low, G. S., \& Lamb, C. W. Jr. (2000). The measurement and dimensionality of brand associations. Journal of Product and Brand Management, 9(6), 350-368.

Macy's, Inc. (2010). Corporate fact book. Macy's, Inc. Re- 
trieved June 1, 2012, from http://www.macysinc.com/ Investors/vote/2010_fact_book.pdf

Martenson, R. (2007). Corporate brand image, satisfaction, and store loyalty: A study of the store as a brand, store brands, and manufacturer brands. International Journal of Retail and Distribution Management, 35(7), 544555.

Matzler, K., Grabner-Krauter, S., \& Bidmon, S. (2008). Risk aversion and brand loyalty: The mediating role of brand trust and brand affect. Journal of Product and Brand Management, 17(3), 154-162.

Morganosky, M. A. (1990). Store and brand type influences on the perception of apparel quality: A congruity theory approach. Clothing and Textiles Research Journal, 9(1), 45-49.

Moschis, G., Curasi, C. F., \& Bellenger, D. (2003). Restaurant-selection preferences of mature consumers. Cornell Hotel and Restaurant Administration Quarterly, 44(4), 51-60. Retrieved June 3, 2012, from http://cqx. sagepub.com/content/44/4/51.citation

Nielsenwire.com. (2008). Private label brands gain favour among U.S. consumers. nielsenwire.com. Retrieved June 5, 2012, from http://blog.nielsen.com/nielsenwire/consumer/private-label-brands-gain-favor-among-us-consumers

Private Label Manufacturers Association. (2009). Store brands achieving new heights of consumer popularity and growth. Market update. Retrieved February 3, 2010, from http://plma.com/storeBrands/sbt08.html

Romaniuk, J., \& Sharp, B. (2003). Measuring brand percep- tions: testing quantity and quality. Journal of Targeting, Measurement and Analysis for Marketing, 11(3), 218229.

Semeijn, J., van Riel, A. C. R., \& Ambrosini, A. B. (2004). Consumer evaluations of store brands: Effects of store image and product attributes. Journal of Retailing and Consumer Services, 11(4), 247-258.

Stone, A. (2009). Advantages of private label products. Ezine@rticles ${ }^{\circledR}$. Retrieved April 14, 2011, from http:// ezinearticles.com/?Advantages-of-Private-Label-Products\&id=2891496

Sudhir, K., \& Talukdar, D. (2004). Does store brand patronage improve store patronage? Review of Industrial Organization, 24(2), 143-160.

Symphony IRI Group. (2006). The changing role of private label. SymphonyIRIGroup. Retrieved February 20, 2010, from http://www.symphonyiri.eu/NewsEvents/PressReleases/tabid/97/ItemID/843/View/Details/Default.aspx

Team, T. (2010). Private label surge threatens Polo Ralph Lauren. TREFIS. Retrieved June 2, 2012, from http:// www.trefis.com/stock/rl/articles/18432/polo-ralph-lauren-threatened-by-private-label-surge/2010-07-07

Vahie, A., \& Paswan, A. (2006). Private label brand image: Its relationship with store image and national brand. International Journal of Retail \& Distribution Management, 34(1), 67-84.

Visser, E. M., Du Preez, R., \& Van Noordwyk, H. S. (2006). Importance of apparel store image attributes: Perceptions of female consumers. SA Journal of Industrial Psychology, 32(3), 49-62. 